\title{
СУЧАСНІ ПІДХОДИ ДО ЦІННОСТЕЙ: ПЕДАГОГІЧНИЙ ПІДХІД ДО ТРАНСЦЕНДЕНТАЛЬНОЇ ТА ДИСПОЗИЦИЙОӦ КОНЦЕПЦІї ЦІННОСТЕЙ
}

\section{Олександра Лисенко}

кандидат філологічних наук, доцент кафедри теорії та методики дошкільної і спеціальної освіти педагогічного факультету Прикарпатського національного університету імені Василя Стефаника ORCID ID 0000-0002-1029-7843

\section{lysenkowa@gmail.com}

Анотація. У статті розглянуто екзистенційні проблеми людського буття. Автором проаналізовано поняття цінностей, що присутні в багатьох наукових дисциплінах. Людина реалізується та формується через цінності, тому можемо говорити про аксіотропізм, присутній у людській природі. Позитивні цінності формують людину, антицінності іï руйнують. Проаналізовано трансцендентальні та диспозиційні концепції цінностей, здійснено їхній культурологічний і педагогічний аналіз.

Ключові слова: цінності; виховання; педагогічний підхід; культурологічний підхід; трансцендентальні концепції цінностей; диспозиційні концепції цінностей.

Постановка проблеми в загальному вигляді. До фундаментальних екзистенційних проблем належать питання: ким є людина? Яка рушійна сила у їі житті є визначальною? У чому зміст життя людини? Відповіді на ці та інші запитання дуже різняться. Однак найважливішим залишається підгрунтя аксіологічного персоналізму, до якого людська особистість повсякчас звертається та інтерпретує в контексті багатого й різнобічного світу цінностей.

Аналіз основних досліджень і публікацій. Характеристиками цінностей та їхньої значущості займались такі учені: Л. Архангельський, О. Здравомислов, Н. Наумова， І. Фролов， Я. Щепанський. Характер цінностей досліджували Л. Архангельський, В. Отрут, С. Рубінштейн, Л. Фролович. Взаємозв'язки ціннісних орієнтацій і проблеми мотивації в загальнопсихологічному підході, самоактуалізації, задоволеності, активності особистості розглядали В. Асєєв, В. Бакіров, Ю. Забродін, А. Маслоу та ін. Так, ученими доведено, що цінності характеризують спрямованість особистості й виявляються, насамперед, у мотивах діяльності.

Формулювання цілей статті. Визначити та акцентувати увагу на проблемі сучасних підходів до вивчення цінностей загалом та педагогічного зокрема. Окрему увагу звернути на трансцендентальні та диспозиційні цінності.

Результати дослідження. Оскільки тварина керується імпульсами біологічних інстинктів, а людина поводить себе в житті згідно із сформованими та вихованими цінностями, про «дозрілість людської особистості, про іiі досконалість великою мірою свідчить те, що вона сповідує певні цінності» $[1$, 
с. 173]. Саме цінності залишаються предметом багатьох досліджень сучасних учених, адже саме вони інспірують думку, почуття та дії людини, виступають життєвими цілями. Поняття цінностей присутне в однаковій мірі в повсякденному житті, у рефлексіях багатьох наукових дисциплін; адже кожна спроба розуміння та вивчення людини абстрагована від аксіології наперед приречена на невдачу.

Найважливішим залишається вивчення підгрунтя аксіологічного персоналізму, до якого людська особистість повсякчас звертається та інтерпретує в контексті багатого та різнобічного світу цінностей.

Проблемою цінностей займаються психологічні науки та педагогіка [2, с. 54], бо конкретні аксіологічні опції доводять вирішальний вплив на життя людини, на модель сім'ї, методи виховання тощо. Цінності досліджує також соціологія, яка аналізує виокремлені людиною суспільні вартості й пов'язану із цим поведінку. У колі соціологічних досліджень перебувають актуальні трансформації шкали цінностей [4, с. 47].

Оскільки цінності складають осередок людського життя, то філософська антропологія своє природнє доповнення знаходить в аксіології. Життя людини це ціннісне навчання в контексті життєвих ситуацій як індивідуальноекзистенційних, так і суспільних. Активна життєва позиція - це спочатку розуміння, а потім оцінка та вибір належних цінностей. Людина реалізується та формується через цінності, тому можемо говорити про аксіотропізм, присутній у людській природі. Позитивні цінності формують людину, антицінності іiі руйнують. Світ людини, позбавлений цінностей, був би аксіологічно нейтральним та екзистенційно порожнім, бо йому бракувало б правди, добра, справедливості, щастя, любові, краси [5, с. 75]. Це був би здепресоналізований світ, позбавлений людяності та зредукований до біологічно-тваринного виміру. Людське життя втратило б тривалий, глибокий сенс, природну направленість $i$ аксіологічну спрямованість.

Тісний зв'язок людини зі світом цінностей зобов'язує філософію до вивчення аксіологічних проблем. Філософія цінностей обіймає також основні філософські науки: етику, естетику, філософію релігії, філософію культури. Філософія цінностей органічно пов'язана із філософською антропологією, бо неможливо адекватно аналізувати людину, не звертаючи належної уваги на іiі інтелектуально-духовний рівень, який міститься в ціннісному полі. Водночас аксіологія є невід'ємною частиною сформованого людського світопогляду, інтегральним елементом якого $€$ цінності пізнавальні, етичні, естетичні, а також ідейні, зокрема релігійні.

Філософія цінностей $є$ істотною для персоналістичної педагогіки. Наведені погляди підтверджують доцільність філософського аналізу ціннісної проблематики з детальним аналізом актуальної суспільно-світової ситуації, цивілізаційно-культурної та ідеологічно-змістовної. Наявні на сьогодні прояви ліберально-технічної кризи спонукають до вивчення сутності цінностей. 
Аксіологія як автономна філософська дисципліна з'явилась у європейській думці на зламі XIX - XX століть. Її дослідниками були такі вчені-мислителі, як Лотце, Ніцше, Брентано, Мейнонг, Рікерт, Віндельбанд, Шелер, Гартман. Вони розглядали проблематику цінностей у систематично-професійному ракурсі (експлікація), бо філософія від самого початку опосередковано цікавилась тематикою цінностей. Непорозумінням є твердження, що тільки від Канта та сучасної філософії зініційовано філософський аналіз феномена цінностей. Філософія людини завжди тісно співіснувала із філософією цінностей та їі субдисциплінами.

Звернення до історико-філософського матеріалу дозволяє хоча б почасти уявити, яке багатство ідей, способів розуміння та інтерпретації феномена цінностей уже існує в арсеналі філософії, а також усвідомити, як мало ми використовуємо це багатство сьогодні, зокрема в роздумах про цінності в процесі виховання. Ми не можемо претендувати на повноту осмислення всього корпусу ідей, відкриттів і здогадок, але одне, безсумнівно, слід визнати, що головним принципом учення про цінності стало розмежування їх на формальні, трансцендентальні, апріорні, «царство цінностей», 3 однієї сторони, та матеріальні, диспозиційні - 3 іншої. Такий підхід $є$ близьким до введеного Кантом поняття імперативу та максими, які фіксують форми знання для представлення ціннісних феноменів різного походження.

Складність дослідження проблеми зумовлена тим, що саме розуміння трансцендентального надзвичайно багатозначне як в історії філософії, так і в сучасних дослідженнях. Подамо узагальнене уявлення про трансцендентальні знання, долучивши найбільш значущі параметри. До них належать такі: універсальність (усезагальність), апріорність, передумови, протилежність емпіричному, спрямованість на раціональність, об'єктивна значущість, аподиктичність.

Трансцендентальний суб'єкт - це не лише монада, свідомість узагалі, але й інтерсуб'єктивність, що визнає існування та самостійність інших монад, передбачаючи теоретико-антропологічне розширення смислів у комунікативному синтезі інтерпретацій. Це трансцендентально-герменевтичне розуміння мови та цінностей як інтерсуб'єктивних об'єктивно значущих духовних структур (трансцендентальний прагматизм).

Переважає також розуміння цінностей як ціннісного релятивізму, якому, зрозуміло, не було місця в науковому пізнанні, водночас заперечувались загальнолюдські цінності як пусті абстракції, котрі необхідно було заповнити конкретними інтересами, виправдовувались ситуації, коли суб'єкти діяли поза полем моралі, в інтересах політичних, ідеологічних або класових.

Подекуди така позиція зберігається і сьогодні. Визнання іiі помилковості необхідне для правильного розуміння природи $\mathrm{i}$ специфіки ціннісно «навантажених» соціальних і гуманітарних знань. Поєднання чи діалог двох підходів - трансцендентального та диспозиційного спричинить до визнання 
cmійкux, загальнолюдських, соціальних і культурних цінностей, а також рухомих, мінливих, релятивних - групових та індивідуальних переваг і цінностей.

Проблема взірців, що формуються на трансцендентальному рівні, не вирішується однозначно. Вони формуються в тій чи тій культурі стихійно або навмисно, як, скажімо, у релігії, передаються як традиції, засвоюються в процесі навчання та повсякденному житті, реалізуючись на рівні індивідуальних дій.

Однак О. Дробницький, який досліджував проблему моральних цінностей, не вважав, що у своїх учинках люди можуть пунктуально дотримуватися будьяких абстрактних норм i образів. Навпаки, це може спричинити надмірне моралізування, лицемірство. Для теорії моралі та теорії цінностей, без сумніву, цінним $\epsilon$ те, що від повсякденного живого буття свідомості вже відділилась область стійких нормативно-ціннісних уявлень, які зберігаються в суспільній пам'яті. Такі системні уявлення - норми, принципи, поняття добра i зла, справедливості та інші - формуються не в повсякденному спілкуванні і навіть не в одному поколінні, а впродовж історично значущих епох, наголошує учений [6, с. 81].

Цей трансцендентальний рівень існування моральних цінностей доповнюється також системою понять, серед яких загальне розуміння моралі відіграє роль певної теоретичної рамки, перспективи, способу бачення предмета в його історії, що дозволяє виявити певну цілісність емпіричного різноманіття фактографічних репрезентацій - предмет моралі.

Трансцендентальний рівень розгляду цінностей дозволив сформулювати такі проблеми та запропонувати їхнє вирішення в теоріях цінностей, що розробляються не лише філософами, а й педагогами. Передусім це проблеми буття цінностей, їхньої всеохопленості, незалежності, абсолютності відносності, об’єктивності - суб'єктивності, співвідношення понять знання i цінності, класифікації цінностей тощо. Водночас ніхто з дослідників проблеми цінностей та їхнього пізнання, приймаючи трансцендентальний рівень за необхідний для створення теорії цінностей, не зупиняється на ньому.

Вивчення цінностей передбачало також перехід на емпіричний рівень до реальних цінностей, що наповнюють змістом. Відзначимо, що крізь безліч підходів, зокрема розглянутих вище, наявна тенденція розуміння емпіричних цінностей та оцінок як наслідок визначених диспозицій, тобто положень у системі суб'єкт-об'єкт. У радянській філософії, яка не брала до уваги досвід трансцендентального підходу, як ідеалістичного, диспозиційна концепція була визначальною.

Суть цієї концепції у свій час виявив, узагальнив і виклав I. Нарський. Учений виходив 3 того, що жодних об’єктивних цінностей у значенні «надсуб'єктивних» чи матеріальних не існує. Як і значення, стверджував він, цінності - це категорії взаємодії суб'єкта й об'єкта, які володіють диспозиційним характером [7, с. 81]. 
Розрізняючи пізнавальне і ціннісне, I. Нарський водночас наголошував на тісному зв'язку оцінки i пізнання, стверджуючи, що результати пізнання передбачають оцінку, а розуміння цінностей грунтується на пізнанні. У диспозиційній концепції І. Нарського, яку він уважав, мабуть, єдино можливою та універсальною, простежується очевидний гносеологізм, універсальність суб'єктно-об'єктних відносин, які він прагнув доповнити визнанням соціальності та особистісності цих відносин у суспільстві.

Справедливо заперечуючи цінності як певні автономні надсуб'єктні чи матеріальні сутності, він не приймав трансцендентальний рівень філософського розгляду цінностей як всезагальних абстракцій, уважаючи це, неприйнятним ідеалізмом.

Очевидно, що трансцендентальний підхід, який досліджує значущість, а не існування цінностей, як і диспозиційний підхід широко представлені в історії філософії та сучасних концепціях цінностей, тому слід вести мову саме про їхнє взаємодоповнення. Диспозиційно-емпіричний підхід наповнює конкретним, варіативним, соціальним і культурно-історичним змістом абстрактні цінності, що представлені на трансцендентальному рівні в категоріально-філософській формі.

Концепції цінностей і сучасна наука. У XX столітті у філософії науки відбувалась дискусія про роль цінностей у науці: вони $є$ необхідною «рушійною силою» для іiї розвитку чи умовою успішної діяльності вчених служить їхнє звільнення від усіх можливих ціннісних орієнтирів?

Чи можливо повністю виключити із суджень про факти ціннісні переваги i пізнати об'єкт як такий, сам по собі? Чи є необхідним протиставлення фактичності наукового досвіду і цінностей як особливої форми предметності, представленої в культурі?

У попередньо здійсненому аналізі філософського знання ми бачимо, що відповіді на ці питання і введення термінології та способів роздумів над вище вказаними проблемами представлені в Канта, Вебера, Шелера, Гартмана та інших філософів, що досліджували розбіжності знань і цінностей. Водночас формувались ідеали ціннісно нейтрального знання й об'єктивності, особливо на противагу різним формам ідеологічного тиску.

У другій половині $\mathrm{XX}$ століття здійснюється суттєвий поворот до постановки питання по-іншому: етичні імперативи, ціннісно-нормативна структура, що забезпечує автономність науки в демократичному суспільстві, стали розглядатись як необхідні складові росту наукового знання. До цих проблем звертались усі провідні філософи науки: Т. Кун, М. Полані, І. Лакатос, Л. Лаудан та інші. Одним із плідних способів змістовної конкретизації цінностей і ціннісних орієнтацій в науці $є$ їхня інтерпретація історично трансформованої системи норм та ідеалів пізнання.

Подібні цінності є в основі наукового дослідження, тому можливо виявити певний взаємозв'язок власне пізнавальних установок із соціальними ідеалами та 
нормативами; установити залежність пізнавальних ідеалів, норм як від специфіки об'єктів, що вивчаються в той чи той момент наукою, так і від особливостей культури кожної історичної епохи.

Загалом можемо відзначити, що розглядаючи проблему «на рівні суджень», при всьому розмежуванні фактуальних суджень і суджень цінностей існує структурно-генетичний зв'язок між ними, бо всі судження $\epsilon$ в кінцевому рахунку результатом діяльності людини, суб'єктивним образом об'єктивного світу. Конститутивний характер будь-якого теоретичного знання не виключає його ціннісної орієнтації, бо кожна теорія тією чи тією мірою володіє методологічною функцією, що представляє ціннісну орієнтацію, утворену на об'єктивній основі.

Наступна передумова, що вплинула на подальші дослідження - це виявлення, з одного боку, універсального характеру оцінної діяльності суб'єкта пізнання, а з іншого - розширеного арсеналу цінностей індивіда та суспільства. Це призвело до того, що судження цінностей почали узагальнюватись до суджень оцінки, бо під цінностями починаємо розуміти не лише те, що відповідає чи не відповідає вищим моральним та естетичним ідеалам, а й просто відповідність/невідповідність будь-яким, навіть світоглядним, нормам i принципам.

У педагогічній науці цінності розглядаємо у взаємозв’язку 3 поняттями освіти, навчання, виховання, розвитку особистості. Суголосними для нас $\epsilon$ погляди О. Шевнюк щодо основної функції педагогічної освіти - перетворення об'єктивно наявного культурного досвіду людства в процесі оволодіння професійно-педагогічними знаннями, уміннями i навичками в суб'єктивну форму. Наголосимо, що саме суб'єктна функція освіти в неповторній індивідуальній формі актуалізує процеси засвоєння людиною суспільних норм і цінностей в процесі активної перетворювальної діяльності. Завдяки суб'єктній функції педагогічної освіти реалізується «продуктивна» (на противагу «репродуктивній») орієнтація особистості майбутнього педагога на відтворення культури загалом [12, с. 169 - 177]. Покликання майбутнього педагога вбачаємо не лише в необхідності збагатити вихованців різноплановими знаннями, а передусім допомогти їм усвідомити себе в культурному просторі, сформувати самосвідомість. Для досягнення такого результату слід нарешті відмовитись від абстрагування та знеособлення знань, забезпечити натомість їхнє вкорінення в соціальний і національно-культурний грунт.

Сьогодення диктує вихід логіки і структури педагогічної професії за звичні межі індустріально-просвітницького типу мислення 3 його акцентом на предметно-розчленоване сприйняття світу, вузьку спеціалізацію й гіпертрофовану технологізацію діяльності. Цілісне осягання світу, культуру людини можливо повернути, звільнившись від обмеженості предметоцентризму, шляхом занурення операційно-процесуальних аспектів педагогічної професії в сутнісні та культурно-контекстні реалії [11, с. 7]. 


\section{О. ЛИСЕНКО}

\section{Сучасні підходи до цінностей: педагогічний підхід до трансцендентальної та диспозиційної концепції цінностей}

Переконані, що лише визнання майбутнього педагога суб'єктом культури сприятиме не лише готовності засвоїти спеціальні теоретичні та практичні професійні знання i навички, a насамперед відповідально виконувати соціокультурні функції професії, усвідомити суспільну мету професійної діяльності, сприйняти педагогічну професію як життєву цінність.

Отже, у вихованні майбутнього педагога необхідним є аксіологічний підхід. В основі концепції особистісно орієнтованої педагогіки і гуманістичного виховання перебуває трансформація головних педагогічних і філософських ознак категорії «цінності». Убачаємо в цьому діалектику навчально-виховного процесу, який заснований на необхідності єдності вільного розвитку майбутнього педагога і вихованця, із педагогічним керівництвом цього процесу; необхідності адаптації цілей, змісту, форм, засобів і методів виховання i навчання як у закладах вищої освіти, так і закладах дошкільної освіти, школах тощо.

Висновки 3 дослідження і перспективи подальших розвідок у цьому напрямі. Очевидно, що істина та цінності можуть розглядатися як взаємовиключні протилежності лише в тому випадку, коли під ціннісним ми розуміємо довільне, суб'єктивне, ідеологічне чи утилітарне в загальному, будьяке деформуюче начало. У цьому контексті справедливим уважаємо, що наука, істинне знання повинні розвиватися незалежно від ціннісних розміреностей.

Саме цей аспект мав на увазі О. Бакурадзе, який стверджував, щз істина сама не є цінністю. Пізнавальна цінність істини і сама істина - дві різні речі. Не істина $\epsilon$ цінністю, а вона має цінність, саме пізнавальну цінність. Істинна думка цінна тому, що вона цінна. Без цього вона не мала б цінності $[8$, с. 85].

Підсумовуючи, наголосимо, що педагогічна освіта майбутніх педагогів повинна здійснювати не лише вузькоспеціалізовану підготовку, але й формувати, виховувати духовно багату індивідуальність педагога, готувати до життя в мінливому світі, розвивати в нього здатність сприймати критично інформацію та приймати ефективні рішення.

\section{СПИСОК ВИКОРИСТАНИХ ДЖЕРЕЛ}

1. Jan Paweł II (1994). Osoba i czyn oraz inne studia antropologiczne. Lublin, Poland.

2. Matusiewicz, C. (1975). Psychologia wartości. Warszawa-Poznań, Poland.

3. Misztal, H. (1990). Problematyka wartości w socjologii. Warszawa, Poland.

4. Mariański, J. (2001). Kryzys moralny czy transformacja wartości? Lublin, Poland.

5. D.von Hildebrand (1953). Christian Ethics. New York, the USA.

6. Дробницкий, О.Г. (1974). Теоретические основы этики Канта. Философия Канта и современность. Москва, Россия.

7. Нарский, И.С. (1969). Диалектическое противоречие и логика познания. Москва, Россия.

8. Бакурадзе, О.М. (1966). Истина и ценность. Вопросы философии, 7, 80-87. 
Сучасні підходи до цінностей: педагогічний підхід до трансцендентальної та диспозиційної концепції цінностей

\title{
СОВРЕМЕННЫЕ ПОДХОДЫ К ЦЕННОСТЯМ: ПЕДАГОГИЧЕСКИЙ ПОДХОД К ТРАНСЦЕНДЕНТАЛЬНОЙ И ДИСПОЗИЦИОННОЙ КОНЦЕПЦИИ ЦЕННОСТЕЙ
}

\author{
Александра Лысенко \\ кандидат филологических наук, доцент кафедры теории и методики \\ дошкольного и специального образования педагогического факультета \\ Прикарпатского национального университета имени Василия Стефаника \\ ORCID ID 0000-0002-1029-7843 \\ lysenkowa@gmail.com
}

Аннотация. В статье рассматриваются экзистенциальные проблемы человеческого бытия. Автором проанализировано понятие ценностей, которые присутствуют во многих научных дисциплинах. Человек реализуется и формируется через ценности, поэтому можем говорить о аксиотропизме, который в той или иной мере присутствует в человеческой природе. Положительные ценности формируют человека, антиценности ее разрушают. Анализируются трансцендентальные и диспозиционные концепции ценностей, осуществляется их культурологический и педагогический анализ.

Ключевые слюва: ценности, воспитание; педагогический подход; культурологический подход; трансцендентальное концепции ценностей; диспозиционные концепции ценностей.

\section{CURRENT APPROACHES TO VALUES: A PEDAGOGICAL APPROACH TO TRANSCENDENTAL AND DISPOSITIONAL VALUE CONCEPTS}

\section{Oleksandra Lysenko}

Candidate of Philological Sciences, Associate Professor of the Department of Theory and Methodology of Preschool and Special Education

Vasyl Stefanyk Precarpathian National University

ORCID ID 0000-0002-1029-7843

\section{lysenkowa@gmail.com}

Abstract: The article deals with the existential problems of human being. The author analyzes the concepts of values that are present in many scientific disciplines. The human is realized and formed through values, so we can talk about axiotropism, being present in human nature. Positive values form a person, their antivalues destroy them. The transcendental and dispositional concepts of values are analyzed, their cultural and pedagogical analysis is carried out. These values remain the subject of modern scholars' many studies. The most important thing to study is the basis of axiological personalization.

Problems of values are engaged in psychological sciences and pedagogy. In the number of sociological researches there are relevant transformations of the value scale.

An active life position is an initial understanding, and then an assessment and selection of proper values. The human is realized and formed through values.

The close relationship between a man and the world of values obliges philosophy to study axiological problems. Philosophy of values embraces also the basic philosophical sciences: ethics, aesthetics, philosophy of religion, and philosophy of culture. The philosophy of values is organically linked with philosophical anthropology. The philosophy of values is essential for personalistic pedagogy. 


\section{О. ЛИСЕНКО}

Сучасні підходи до цінностей: педагогічний підхід до трансцендентальної та диспозиційної концепції цінностей

Axiology as an autonomous philosophical discipline appeared in European thought at the turn of the nineteenth and twentieth centuries. Its researchers were such scholars as Lhotse, Nietzsche, Brentano, Maingong, Rickert, Windelband, Scheler, and Hartmann.

The study of values also includes the transition to the empirical level, to the real values that fill the content. In pedagogical science, we consider the values in correlation with the notions of education, training, education, and development of personality. So, in the future teacher's training an axiological approach is needed.

Key words: values; education; cultural approach; transcendental value concept, dispositional value concept.

\section{REFERENCES (TRANSLATED AND TRANSLITERATED)}

1. Jan Paweł II (1994). Osoba i czyn oraz inne studia antropologiczne. Lublin, Poland.

2. Matusiewicz, C. (1975). Psychologia wartości. Warszawa-Poznań, Poland.

3. Misztal, H. (1990). Problematyka wartości w socjologii. Warszawa, Poland.

4. Mariański, J. (2001). Kryzys moralny czy transformacja wartości? Lublin, Poland.

5. D.von Hildebrand (1953). Christian Ethics. New York, the USA.

6. Drobnytskiy, O.G. (1974). Theoretical fundamentals of Kant's ethics. Kant's philosophy and the present. Moscow, Russia.

7. Natskiy, I. S. (1969). Dialectic contradiction and logics of knowledge. Moscow, Russia.

8. Bakuradze, O.M. (1966). The truth and value. Voprosy filosofii, 7, 80-87.

Матеріали надійшли до редакції 06.12.2018 р. 